\title{
Management of the innovative activity of the enterprises in investment-based construction industry
}

\author{
Gulsina Zagidullina ${ }^{1 *[0000-0002-3413-7676}$, Rufina Ivanova ${ }^{10000-0002-2167-5627]}$, Idelia Badykova2[0000-0002-9072-3856], \\ Ella Biktemirova ${ }^{10000-0002-4165-3134]}$, and Timur Azhimov 3[0000-0002-4165-3134]
}

${ }^{1}$ Kazan State University of Architecture and Engineering, 420043 Kazan, Russia

${ }^{2}$ Kazan State National Research Technological University, 420111 Kazan, Russia

${ }^{3}$ Moscow State University of Civil Engineering, 129337 Moscow, Russia

\begin{abstract}
The study is devoted to scientific provisions and principles of economic development of construction organizations in modern conditions. Based on the study of the theory of economic development, a retrospective analysis of the cyclical nature of construction production, the main factors and directions of their interaction are systematized. Economic and mathematical modeling of the real economic development of construction production was carried out. New approaches to assessing and ensuring the effective functioning of construction organizations are proposed, including substantiation of the target setting of the organization's activities, classification of factor space multidimensional statistical analysis, determination of the optimal ratios of the main technical and economic indicators that ensure the financial and economic stability of construction organizations. The developed models of innovative development of a construction organization are based on increasing the level of total resource productivity. It has been proven that there is a close relationship between the level of economic development and the financial sustainability of a construction organization. An increase in the level of innovative activity in construction production leads to an increase in the financial strength of the organization. The revealed relationship gave the basis to form an algorithm for managing the innovative development of a construction organization on the basis of structure regulation of production costs. The forms and methods of stimulating the economic growth of construction organizations have been substantiated, which consist in improving the system of relations between the participants in the investment process being a significant reserve for economic growth.

Keywords. Innovative development, financial and economic sustainability, investment and construction complex, simulation model of analysis and management of innovative development.
\end{abstract}

\section{Introduction}

Ensuring sustainable economic development of construction enterprises requires a coordinated solution to the problems of forming technological, institutional and

*Corresponding author: bikti77@yahoo.com 
organizational structures, able to combine all the necessary elements into a general reproductive process of economic potential growth. An analysis of the current situation leads to the conclusion that the most significant factors determining the economic development of construction enterprises in the coming years are the speed of achievement and sustainability of macroeconomic stabilization, and an increase in investment activity [1-3].

Stabilization and a gradual increase in business, including investment, activity with all the funds available to the state are vital. No consensus among practitioners and economists has not yet been achieved on the issue of the tactical implementation of the strategy. One of the most important problems is whether the market mechanism in its pure form is able to create conditions for economic growth and full use of all available production resources. It can ensure the satisfaction of all socially significant needs and to what extent of necessity the government intervention is $[4,5]$.

Depending on the scientific views and the accepted principles of economic policy, researchers have different approaches to its solution. At the same time, it should be noted that a generally recognized position has been formed in world and native economic thought. It's that the market economy needs a clear legal formulation of production and economic relations. It needs the development of a system of production rules and commercial activities. As well as strict control over their observance by the state is needed. Without its corrective role, the economy can spontaneously develop in the direction of creating shadow structures. It will destroy the market environment, with the self-regulation mechanism $[6,7]$.

The reason for the current difficulties in ensuring the sustainable operation of enterprises in the construction sector is the decline in investment activity. The other reason we see in the strategic task solving in the growth of economic potential $[8,9]$.

Many issues related to ensuring sustainable economic development of construction organizations remain poorly studied and debatable both in economic science and in economic practice [10-12]. Organizational, economic and legal mechanisms, which are an essential reserve and a condition for economic development, also require further research and testing [13, 14]. Native research in this area that has been unfolding at the present time does not yet represent a unified concept that comprehensively covers various areas, assessment methods, criteria and factors of economic development $[15,16]$. To an even lesser extent, the system of levers is linked, which makes it possible to implement the theoretical concept in practice [17-19].

The solution of the set tasks determines the relevance of the research topic, both in theoretical and practical terms [20,21]. The aim of the study is to substantiate the theoretical and methodological principles of the formation of an economic mechanism for ensuring sustainable development and functioning of construction enterprises in modern conditions

The goal can be achieved by solving the following main tasks:

- a retrospective analysis of the patterns in the development of construction production, taking into account the impact of cyclical fluctuations and the study of the reasons for the slowdown in its economic development, as well as the specifics construction organizations functioning in modern conditions;

- carrying out a multidimensional statistical analysis of the factor space that forms the final result of the activities of construction organizations;

- quantitative assessment of the real level of economic development of construction organizations;

- a market mechanism development for effective functioning of construction organizations and the formation of a strategy for their development, with the characteristics of the external environment. 


\section{Methods}

\subsection{The relationship and sequence of research methods used}

Our research was conducted using a set of economic and mathematical methods.

1. The survey of environmental factors, the study of the quantitative relationship was carried out in the work using the method of expert assessments.

2. The study of the factors of the external and internal environment, the identification of factors that affect the final result of the activities of construction organizations, was carried out in the work using the method of main components.

3. Quantitative assessment of the relationship between the level of innovative development and the indicators of financial stability of the enterprise was carried out using correlation and regression analysis.

4. The general scheme of the study and the relationship between the economic and statistical methods used are shown in Fig. 1.

\section{Beginning}

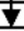

1. Determination of the real level of economic development of a construction company

1.1. Quantitative assessment of economic growth (time series analysis):

1.2. Development and analysis of a variant of the model of innovative development of the enterprise.

1. Development and use of a mechanism for controlling factors, influencing economic growth of the construction company (industry).

2.1. Selection of factors affecting the final result of the construction enterprise (method of expert assessments)

2.2. Determination of factor weights and trimming of factors with low weight (principal component

3. Investigation of the relationship between the financial stability of an enterprise and the level of innovative
development of a construction enterprise. Planning the level of innovative development and financial
sustainability of a construction company (correlation and regression analysis)3.1. Determination of the safety
limit of the enterprise at the planned level of economic development, taking into account a certain threshold of
profitability and a margin of financial strength (methods of financial management)

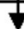

4. Development of a simulation model for managing the level of innovative progress, taking into account the determination of the optimal combination of technical and economic indicators, changes in resource efficiency, interchangeability of resources

5. Development of the optimal option for the development of the enterprise and measures to increase the level of innovative development of construction production

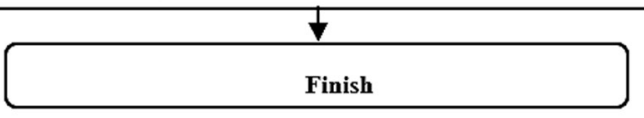

Fig. 1. General scheme of the research methodology.

\subsection{Methodological principles of substantiating the boundaries of financial and economic sustainability of construction enterprises}

Cardinal changes in the Russian economy and overcoming the crisis situation in this regard require financial stabilization of society, the basis of which is the financial stability of 
enterprises. Therefore, it is especially relevant to be able to at a high level, taking into account the richest Western experience, to determine the financial stability of enterprises, factors influencing it and indicators that measure it. Here it is necessary to note the factors that complicate its assessment. The phase of the economic cycle in which the country's economy is located significantly affects the financial stability of enterprises. During a crisis, the rate of sales of products lags behind the rate of production. In general, the incomes of subjects of economic activity are decreasing, and the scale of profits is even decreasing in absolute terms. All this leads to a decrease in the liquidity of enterprises, their solvency.

The drop in effective demand, characteristic of the crisis, leads not only to an increase in non-payments, but also to an aggravation of the competition. Its acuteness is an important external factor of financial stability.

In addition, tax and credit policies, the degree of development of the financial market, general political stability, and property relations serve as serious macroeconomic factors for the stability of an enterprise.

The most important signs of financial stability are the ability to pay and the availability of resources for the development of the enterprise, which, in turn, can be attributed to the most important not only financial, but also general economic problems. After all, insufficient financial stability can lead to the insolvency of the enterprise, and if the financial condition worsens, it can lead to bankruptcy, and excessive financial stability puts obstacles in the way of the development of enterprises, burdening their costs with excessive stocks and reserves. Therefore, it seems appropriate to consider different facets of the financial stability of construction organizations.

Table 1. Characterization of external and internal analysis.

\begin{tabular}{|c|c|c|}
\hline Division & External analysis & Internal analysis \\
\hline $\begin{array}{l}\text { The objectives of the } \\
\text { analysis }\end{array}$ & $\begin{array}{l}\text { Evaluation of the profitability of the } \\
\text { enterprise, the intensity of capital } \\
\text { use, the financial position as a whole }\end{array}$ & $\begin{array}{l}\text { Evaluation of profit, the structure } \\
\text { of the cost price, the reasons for } \\
\text { deviations from the standards of } \\
\text { prices and costs }\end{array}$ \\
\hline Analysis tasks & $\begin{array}{l}\text { Definition and evaluation: } \\
\text { a) property status as of the date of } \\
\text { the report; } \\
\text { b) financial stability and solvency; } \\
\text { c) the intensity of the use of capital } \\
\text { and its profitability; } \\
\text { d) changes in financial position; } \\
\text { e) distribution of profits and } \\
\text { attraction of other sources of capital } \\
\text { into circulation; } \\
\text { f) the relationship of the enterprise } \\
\text { with financial markets, suppliers and } \\
\text { consumers }\end{array}$ & $\begin{array}{l}\text { Control, planning and } \\
\text { organization of the enterprise }\end{array}$ \\
\hline $\begin{array}{l}\text { Character of the } \\
\text { information resources } \\
\text { used }\end{array}$ & Reporting data published & Reliable internal information \\
\hline Analysis consumers & $\begin{array}{l}\text { External consumers }- \text { banks, } \\
\text { enterprises, the public }\end{array}$ & $\begin{array}{l}\text { Analysts }- \text { specialists of the } \\
\text { enterprise }\end{array}$ \\
\hline Using analysis results & $\begin{array}{l}\text { Determines the relationship of the } \\
\text { enterprise with shareholders, } \\
\text { creditors, tax authorities, its position } \\
\text { in the industry }\end{array}$ & $\begin{array}{l}\text { It is used to assess the fulfillment of } \\
\text { the tasks assigned to the enterprise } \\
\text { and to develop development } \\
\text { programs for the future. }\end{array}$ \\
\hline
\end{tabular}


Economic analysis and planning are the most important elements of construction production management. The main function of analytical work is to reveal deficiencies, to identify internal production reserves.

The primary task of analyzing the financial and economic activities of enterprises is to identify the objective possibilities of organizing their normal operation in market conditions, i.e., internal and external reserves that provide the minimum level of profitability required for normal functioning.

The presence of various categories of users of the analytical material of the analysis presupposes the division of the analysis of enterprises' activity into external and internal. Their goals and objectives inherent in each type of analysis become signs of dividing the analysis into internal and external. Among other signs we see the nature of the sources of information used and consumers of analytical material.

The concept of external and internal analysis according to features is presented in Table 1.

Financial stability is the guarantee of survival and the basis for the stable position of an enterprise in market conditions. It reflects a state of financial resources in which an enterprise, freely maneuvers its funds. It is able to ensure an uninterrupted process of production and sale of products, as well as to create conditions for the development of production. To assess the financial stability of an enterprise, an analysis of its financial condition is required. The financial condition of an enterprise can be assessed using a set of indicators that reflect the availability, placement and use of financial resources. The analysis of the financial condition should be a deep, scientifically grounded study of financial relations and the movement of resources in a single production and economic process. During the analysis, it is necessary to determine the profitability and financial stability of an enterprise, to study the efficiency of its use of financial resources, to establish the position of an economic entity in the financial market, to quantitatively measure its competitiveness. As well as to assess the degree of financial measures implementation, programs, plan of financial indicators and measures developed to eliminate the identified deficiencies and to increase the return of resources. The financial condition of an economic entity is a characteristic of its competitiveness, i.e., solvency and creditworthiness, use of resources and capital, fulfillment of obligations to the state and partners. The movement of any inventory and resources is accompanied by the formation and expenditure of funds. Therefore, the analysis of the financial condition of the enterprise, the calculation of basic finance and economic indicators occupies a key place in our study.

\subsection{Management of innovative development for the Enterprises in Investment based Construction Industry}

As a result of the study, the following was obtained:

The intra-industry aspects of economic growth in construction are considered on the study of the dominant directions of modern economic theory in the field of production.

A quantitative assessment of the real economic growth in construction has been carried out on a retrospective analysis of patterns in the development of construction production using the theory of factor models. Inertial and innovative sources of growth in construction products have been identified.

Innovative development in modern conditions should be an object of internal planning and management. A stable and effective operation of the enterprise is possible with proper management and regulation of the innovative development parameters of construction production. Statistical data on the activities of construction enterprises in the Republic of Tatarstan were analyzed in building a simulation model. On the basis of calculations using the method of principal components, the economic indicators of economic activity of 
construction organizations were identified, which have the greatest impact on the rate of profit growth. Let us introduce the notation for these indicators:

$\mathrm{XI}$ - mechanical labor ratio;

$\mathrm{X} 2$ - capital-labor ratio;

$\mathrm{X} 3$ - fulfillment of contractual obligations;

$\mathrm{X} 4$ is the volume of economic ties;

$\mathrm{X} 5$ is the ratio of workers and engineers;

X6 - state order level.

A simulation model was chosen as the main method for studying a complex system for managing the process of innovative development of construction production. The model was used for constructing various options for the financial and economic state of construction production at the planned level of total resource productivity.

The initial data for the model are: - the total return of production resources in the allowable interval change $\left(v_{\min }=0,46\right) \leq v \leq\left(v_{\max }=3,74\right)$.

$A, K, L, M$ - absolute indicators obtained during the model development (1):

$$
Y=A \cdot K^{\alpha} \cdot L^{\beta} \cdot M^{\prime},
$$

where $A$ is a parameter that takes into account the influence of unaccounted factors;

$K$ is the actual average annual growth rate of fixed assets;

$L$ is the actual average annual growth rate of the number of workers employed in the construction industry

$M$ - the actual average annual growth rate of material resources;

$Y$ is the actual average annual growth rate of the volume of construction and installation works.

From the calculation of $Y$, the total resource productivity is determined by the formula:

$$
\alpha+\beta+\gamma,
$$

where $\alpha$ is the coefficient of elasticity for fixed assets;

$\beta$ is the coefficient of elasticity for labor resources;

$\gamma$ - coefficient of elasticity for material costs.

The authors have developed models of innovative development of construction production based on an increase in the level of total resource productivity. The quantitative dependence of the level of innovative development on the level of resource productivity is presented in the form of a nomogram (Fig. 2).

Level of innovation activity of the investment construction complex

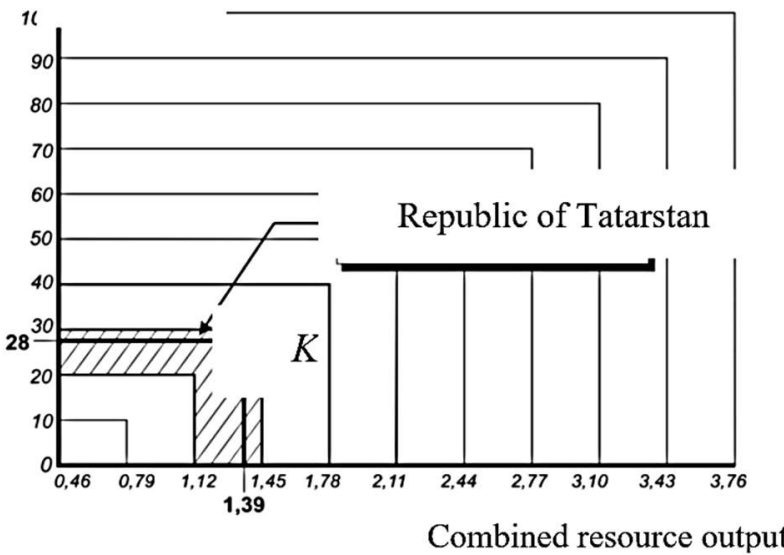

Fig. 2. Nomogram for determining the level of innovative development for the investment and construction complex, depending on the total resource yield. 
The calculated parameters of the intensive development model make it possible to quantitatively determine the return on production resources to ensure a given level of innovative development of construction production. The developed nomogram greatly simplifies the methodology for calculating the level of innovative development of production. It can be used in the practice of production and economic activities of construction enterprises. The groups of factors that have the most significant impact on the final result of the financial and economic activities of a construction company have been identified and quantified with the use of multivariate statistical analysis. Based on the study of world experience gained in the field of microeconomic analysis, the theory of marginal utility and productivity of production factors, the work carried out calculations to determine the level of production at which a construction company will receive maximum profits or minimum losses, using two principles:

- the first involves comparing gross income and gross costs;

- the second is a comparison of marginal revenue and marginal cost. The comparison of marginal revenue to marginal costs is most effective in solving the problem of maximizing the mass of profit. Comparison of proceeds from the sale of construction products with total, as well as variable and fixed costs is used to determine the highest rate of profit growth. A necessary condition for making a profit is a certain degree of development of construction production, which ensures an excess of proceeds from the sale of products, works and services over production costs. The main factor chain that generates profit can be represented by the following scheme:

- costs of construction production;

- the volume of construction production;

- profit.

The components of this scheme should be under the constant attention and control of the heads of construction companies.

\subsection{Methodology for the analysis development of a simulation model and the process management of innovative development in construction production}

This paper investigates the functional relationship between the volume of construction production, the cost of work and profit.

In foreign practice, this problem is solved on the basis of organizing cost accounting according to the «direct costing» system, which is a necessary attribute of a market economy. The main attention in this system is paid to the study of the behavior of resource costs depending on changes in the volume of construction production, which allows one to make quick decisions on the normalization of the financial condition of the enterprise.

The approach considered in this study makes it possible to achieve a high degree of production and financial accounting, analysis and management decision-making. The authors found that there is a close relationship between the financial stability of a construction company and the level of economic development. It has been substantiated that an increase in the level of innovative development of construction production leads to an increase in the financial strength of the enterprise. The revealed relationship served as the basis for the formation of an algorithm for managing the innovative development of a construction enterprise based on the regulation of the structure of production costs. The proposed methodological approaches have made it possible to develop various financial strategies for the development of a construction company. The authors proposed a methodology for developing a simulation model for analyzing and managing the process of innovative development of construction (Fig. 3). 


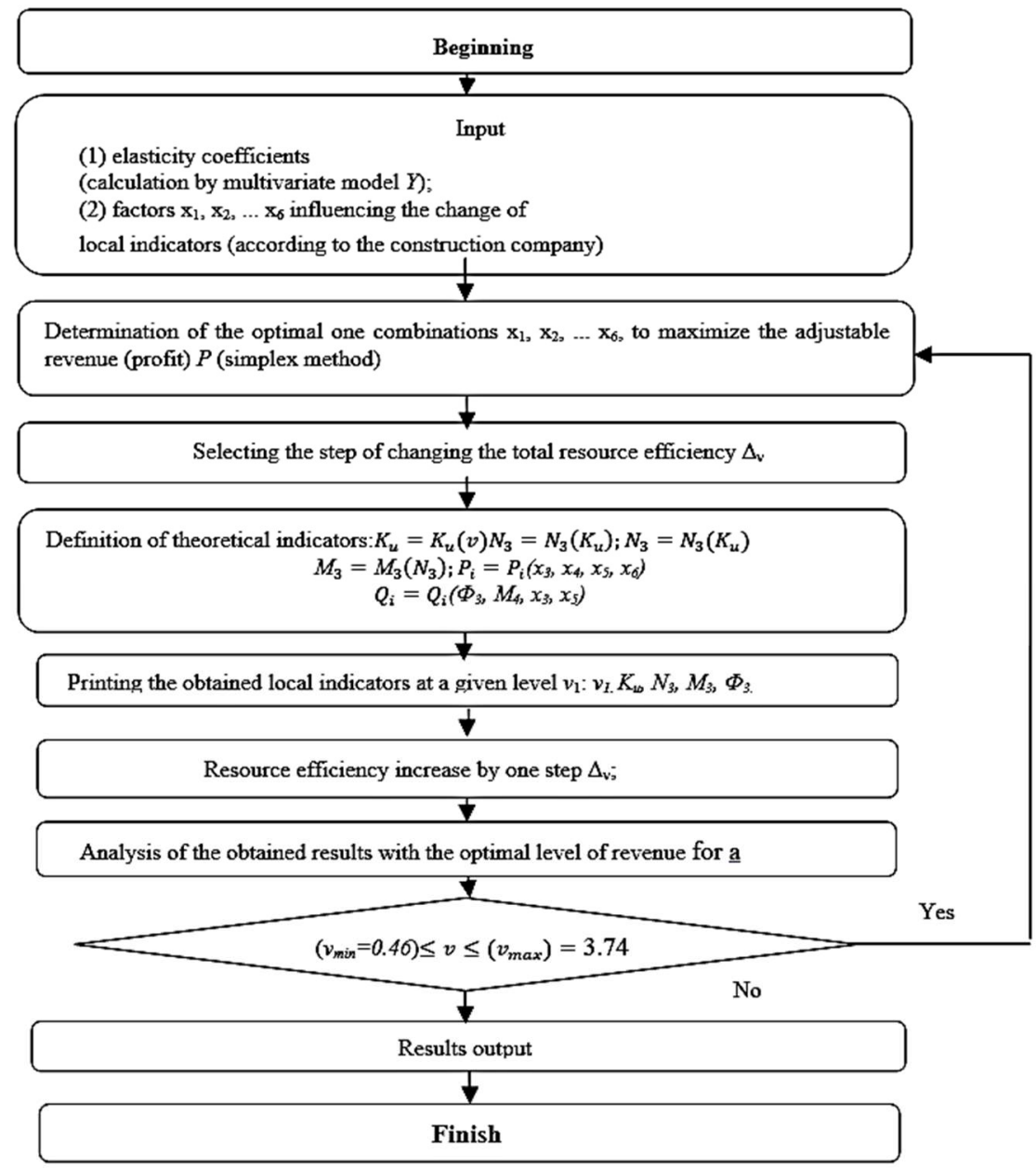

Fig. 3. Algorithm of the simulation model for determining the profit from the sale of construction products at the planned level of innovative development of construction production.

The basis for the construction of the model were: a nomogram of the dependence of the level of innovative development of construction production on the total resource productivity, the conditions for the resources' interchangeability, optimal combinations of technical and economic indicators, multivariate equations of profit, volume of work performed. The total output of production resources is taken as a variable feature.

\section{Results and discussion}

\subsection{The relationship between the financial stability of a construction organization and the level of economic development}

In the course of research, the authors found that there is a close relationship between the financial stability of a construction organization and the level of economic development.

This is confirmed by the correlation analysis of the dependence of some financial ratios on the level of innovative development of construction production. 
The dependence of the share of working capital in the assets of the organization and the share of inventories in current assets with the level of profit is parabolic in nature and has a high correlation coefficient. An increase in the level of innovative development of construction production by $1 \%$ leads to an increase in the financial stability ratio by 2.911 units and an increase in the return on equity by 1.529 units. An increase in the margin of financial strength by $0.1 \%$ is achieved by increasing the level of innovative development of construction production by $10 \%$. A ten percent increase in the level of innovative development of construction production leads to an increase in profit growth by an average of $0.5 \%$. Thus, an increase in the level of innovative development of construction production leads to an increase in the financial strength of the organization (Table 2).

Table 2. Results of the conducted research.

\begin{tabular}{|c|c|c|}
\hline & Indicators & Theoretical regression line equation \\
\hline $\mathrm{Y}$ & Net profit & \\
\hline Y1 & Intensification level & \\
\hline XI & Coverage ratio & $\begin{array}{l}Y=-1562.13+53,59 X 1 \\
R=0.295\end{array}$ \\
\hline $\mathrm{X} 2$ & Absolute liquidity ratio & $\begin{array}{l}Y=-7693.45+172.92 \mathrm{X} 2 \\
R=0.558 \\
X 2=0.051+0.103 \mathrm{Y} 1 \mathrm{R}=0.413\end{array}$ \\
\hline X3 & Share of working capital in current assets & $\begin{array}{l}\mathrm{Y}=13634.873-409.04 \mathrm{X} 3+3.8597 \mathrm{X} 3 \\
\mathrm{R}=0.729\end{array}$ \\
\hline $\mathrm{X} 4$ & Share of inventories in current assets & $\begin{array}{l}Y=44006.1752227 .585 X 4+29.668 X 4 \\
R=0.812\end{array}$ \\
\hline X5 & Autonomy ratio & $\begin{array}{l}Y=13733.37-437.957 X 5+4.308 X 5 \\
R=0.814\end{array}$ \\
\hline $\mathrm{X} 6$ & Maneuverability ratio & $\begin{array}{l}\mathrm{Y}=3344,27+26,38 \times 6 \\
\mathrm{R}=0,641\end{array}$ \\
\hline $\mathrm{X} 7$ & Equity to borrowed capital ratio & $\begin{array}{l}\mathrm{Y}=3552.04+5.61 \mathrm{X} 7 \\
\mathrm{R}=0,419\end{array}$ \\
\hline $\mathrm{X} 8$ & Return on equity & $\begin{array}{l}\mathrm{X} 8=92.534+1.529 \mathrm{Y} 1 \\
\mathrm{R}=0.310\end{array}$ \\
\hline X9 & Financial stability ratio & $\begin{array}{l}X 9=-67.957+2.911 Y 1 \\
R=0.757\end{array}$ \\
\hline $\mathrm{X} 10$ & Return on investment & $\begin{array}{l}\mathrm{X} 10=166.516+2.908 \mathrm{Y} 1 \\
\mathrm{R}=0.356\end{array}$ \\
\hline XII & Return on asset & $\begin{array}{l}\mathrm{XII}=1.170+0.166 \mathrm{Y} 1 \\
\mathrm{R}=0.656\end{array}$ \\
\hline
\end{tabular}

The revealed dependence served as the basis for the formation of an algorithm for managing the innovative development of a construction organization based on the regulation of the structure of production costs.

The proposed approach allows one to achieve a high degree of production and financial accounting, analysis and decision-making management.

An increase in some costs in relation to other, fixed costs leads to an increase in the total amount of production, but after a certain moment the additional production obtained from the addition of the same additional costs will become less and less. This decrease in additional income is due to the fact that new «doses» of changing resources are combined with fewer and fewer fixed resources. All of the above mentioned is the law of diminishing returns. In this regard, managers are faced with the task of choosing the most optimal option for the development of a construction organization.

After this stage, measures are being developed to increase the level of innovative development of construction production. The development of a development strategy for a 
construction organization is based on planning the level of innovative development and determining the rate of profit growth. On the basis of the theoretical parameters of the model, the value of the theoretical growth rate of the volume of construction production is determined.

The size of the profit earned makes it possible to predict the activities of a construction organization and manage all types of resources with the aim of the most profitable development strategy (Fig. 4). The studies carried out give an idea of the growth of profits and the financial position of a construction organization at certain levels of innovative development of production.

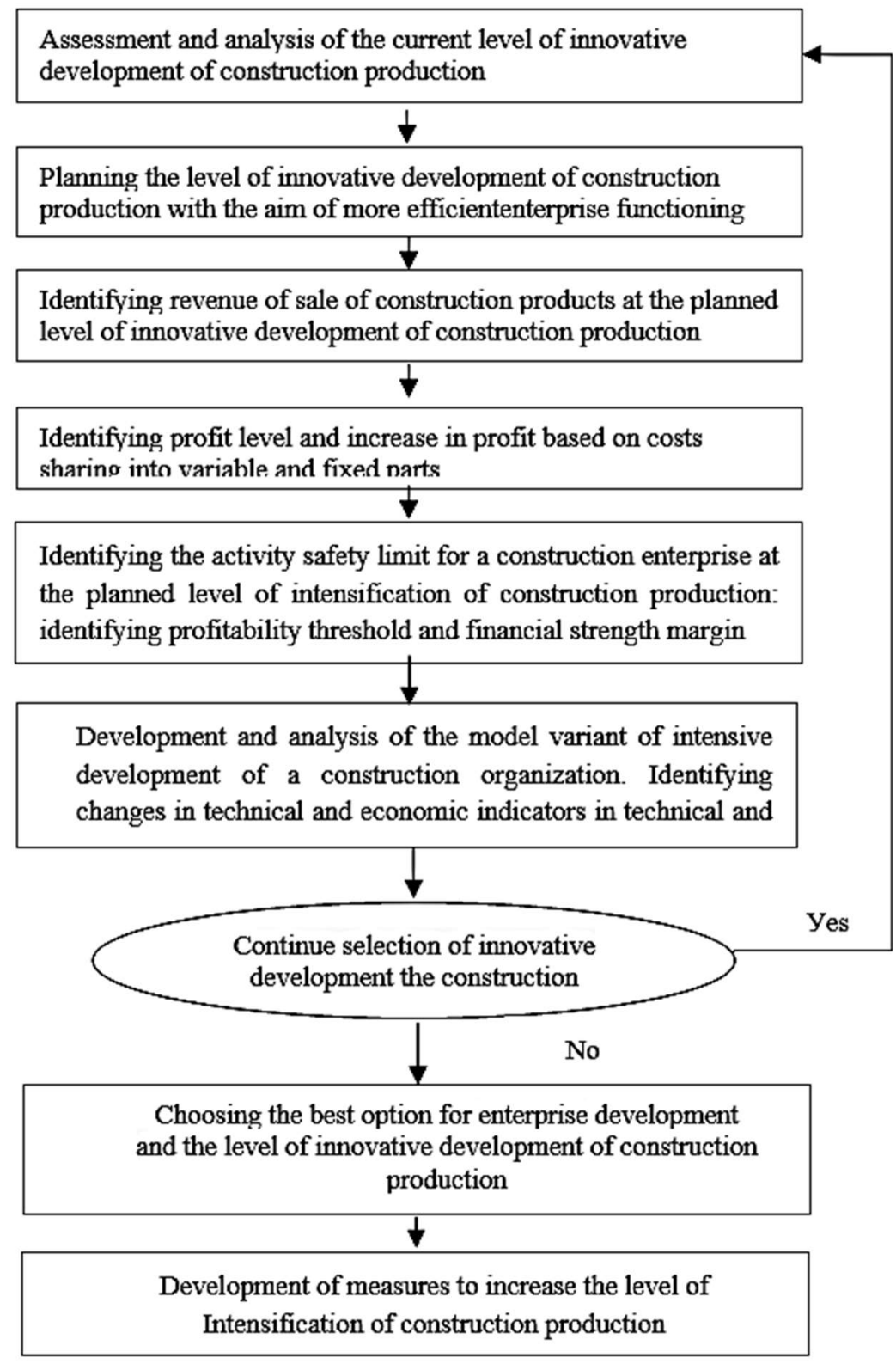

Fig. 4. Enlarged control scheme for the intensification of construction production. 


\section{Conclusion}

The result of the simulation model is the forecast of the level of innovative development of construction production, the rate of replacement of the number of employees with basic production assets, mechanical and capital-labor ratio of the construction enterprise, profit and volume of construction production at various levels of total resource efficiency. Further analysis involves the development of options for a strategy for the innovative development of production. The proposed new methodological approach can be used in the practice of in-house planning of construction organizations. It allows one to manage the process of innovative development of construction production, to influence its level, while achieving optimal use of resources.

In the work, the calculations of the coefficients of the interchangeability of resources are carried out. According to its economic content, the indicator determines the efficiency of construction production, since it provides a commensuration of the result of production (Y) and the total costs of living and materialized labor (in a single labor expression). This indicator can be taken as a generalizing indicator when assessing the economic efficiency of the production activities of construction organizations. The paper investigates the relationship of the generalizing indicator with local indicators characterizing the effectiveness of the use of the three main elements of the production process (living labor, objects and means of labor). Calculations show that the higher the level of labor productivity and capital productivity, the higher the value of the generalizing indicator. Since the change in labor productivity, capital productivity and material intensity of production is of a multidirectional nature, the calculations of the generalizing indicator allow us to assess the efficiency of using the totality of production resources.

The work builds a simulation model for the analysis and management of the innovative development process and construction production. On the basis of simulation modeling, various scenarios of intensive development are considered, which served as the basis for the development of a mechanism for the effective functioning of a construction enterprise and of management decisions monitoring.

The forms and methods of stimulating the economic growth of construction enterprises have been substantiated. In modern conditions of development of market structures, improving the system of relationships between participants in the investment process is a significant reserve for economic growth.

It seems appropriate to consider the management of relationships between participants in the investment process in the following three aspects:

- economic;

- organizational;

- legal.

The economic aspect consists of creating a motivational mechanism that encourages participants to strictly adhere to contractual conditions.

The organizational aspect includes the improvement of the system of contractual relations as a tool for managing the intensification process, as well as the scientific justification of contractual terms. This is to justify the choice of economic partners, the development of the procedure for negotiating and concluding contracts based on object-to-object schedules of interaction between construction participants.

It is also important to take into account the probabilistic nature of construction production in order to increase the level of reliability of the system of relationships between participants in the investment process.

The legal aspect is to create an effective system of property liability. This requires the improvement of methods for determining economic losses.

The developed algorithm makes it possible to simulate various states of the economic activity of a construction organization to predict the profit and growth rates of construction 
production, as well as, on the basis of the forecast, to plan the optimal volume of construction production and the necessary production resources, taking into account their interchangeability and the level of profit.

\section{References}

1. E. Acar, I. Kofak, Y. Sey, D. Arditi. Use of information and communication technologies by small and medium-sized enterprises (SMEs) in building construction, Construction Management and Economics 23 (7), 713-722 (2005).

2. G.M. Zagidullina, A.R. Mavlyutova. Environmental standardization of residential real estate according to "Green standards», International Scientific Conference Environmental Science for Construction Industry, ESCI, EDP Sciences 193, 16 (2018).

3. J. Zhang, El. Xie, K. Schmidt, H. Li. A new systematic approach to vulnerability assessment of innovation capability of construction enterprises, Sustainability (Switzerland) 8 (1), 1-25 (2016).

4. A. Subbotin, D. Subbotina. Features of formation and functioning of the integrated structures in construction, IOP Conference Series: Materials Science and Engineering 365 (5), 052007 (2018).

5. V.V. Alexeenko, N.S. Seredina. Factor interrelation system of integrated business structure development in construction, Materials Science Forum 931 MSF, 1142-1147 (2018).

6. Marlyne Sahakian. Innovations in Sustainable Consumption: New Economics, Sociotechnical Transitions and Social Practices, Environmental Innovation and Societal Transitions 8, 94-96 (2013).

7. Nikolay Sterev', Hector Rosillo, Toledo Gerardo. Technology, Innovations and Industrial Development, Economic Alternatives 4, 549-559 (2019).

8. Saila Tykkylainen, Paavo Ritala. Business model innovation in social enterprises: An activity system perspective', Joumal of Business Research. Open access (2020).

9. I.R. Nizamova. The position of the world economy and the Russian economy in the system of technological modes, Economic Systems Management: an electronic scientific journal, 11 (71), (2014).

10. S.S. Kudryavtseva, A.I. Shinkevich, V.T. Volov, G.F. Yusupova, J.V. Torkunova, E.R. Khairullina, N.V. Klimova, Irina Y., R.M. Sirazetdinov. A Design of Innovative Development in the Industrial Types of Economic Activity, International Review of Management and Marketing 5 (4), 265-270 (2015).

11. Olga P. Smirnova, Oleg M. Barbakov, Alena O. Ponomareva, Marina V. Vinogradova. Modeling of the Innovation Activity of Russia's Regions, WSEAS transactions on business and economics 16, 403-413 (2019).

12. Alfredo Serpell, Romina Alvarez. A Systematic Approach for Evaluating Innovation Management in Construction Companies, Procedia Engineering 85, 464-472 (2014).

13. Anatolij Asaul, Sergej Ivanov. Problems of Architecture and Construction, World Applied Sciences Journal 23, 80-83 (2013).

14. Mohammadali Noktehdan. Innovation classification and measurement system for construction industry, Shaping the Frontiers of Innovation Management, Budapest, Hungary (2015).

15. G.M. Zagidullina, A.R. Mavlyutova. Environmental standardization of residential real estate according to «Green standards», EDP Sciences 19, 16 (2018).

16. A.I. Romanova, G.M. Zagidullina, R.M. Ivanova, O.A. Kleshcheva, R.M. Sirazetdinov. Peculiarities of Housing Construction Development in the Region, Middle-East Journal of Scientific Research 16 (4), 490-495 (2013).

17. Sulafa Badi, Edward Ochieng. The impact of social power and influence on the 
implementation of innovation strategies: A case study of a UK mega infrastructure construction project, European Management journal (2020).

18. Anatolii Asaul, Mykhaylo Voynarenko, Larysa Dzhulii's, Larysa Skorobohata, Oksana Mykoliuk, Liudmyla Yemchuk. The Latest Information Systems in the Enterprise Management and Trends in their Development, Conference Paper, 409-412 (2019).

19. Mehr Shabnam Yazdani. A review on quality management and innovation in the Iranian construction industry, Proceedings of the international conference in economics and administration. ICEA-FAA (2013).

20. R.M. Ivanova. Investment demand prediction based on economic and mathematical modeling, News of the KSUAE 4, 353-364 (2014).

21. L.A. Kayumova, L.I. Savvab, A.L. Soldatchenkov, L.G. Akhmetova, R.M. Sirazetdinov. The Technology of Forming of Innovative Content for Engineering Education, International journal of Environmental \& science education 11 (0.9), 3029-3039 (2016).

22. A.N. Afanasyeva, G.M. Zagidullina, A.I. Romanova. Experience in the Region to Increase the Availability of Housing Services, Mediterranean Journal of Social Sciences 6 (4), 549-554 (2015). 